Права людини в Україні та у зарубіжних країнах:

проблеми теорії та нормативно-правової регламентації

DOI https://doi.org/10.36059/978-966-397-210-7/328-348

Полішук Н. Р.,

кандидат юридичних наук, асистент кафедри теорії та історії держави і права

Національного університету біоресурсів

і природокористування України,

м. Kuїв

\title{
ПРАВО НА ОСВІТУ ОСІБ З ОСОБЛИВИМИ ОСВІТНІМИ ПОТРЕБАМИ
}

Анотація. Визнання прав осіб з особливими освітніми потребами, їхніх інтересів, потреб, надання допомоги у процесі соціалізації та вибору професійної діяльності є надзвичайно важливими для розвитку сучасної системи освіти. Однією із складових гуманітарної політики найбільш розвинених країн світу є успішне впровадження інклюзивної освіти. Оскільки популяризація інклюзії в суспільних відносинах свідчить, наскільки держава захищає невід'ємні права людини. Україна як вагома частина європейського простору поступово входить $в$ оновлений освітній процес, що враховує світові стандарти освіти. Важливим $\epsilon$ дослідження правового регулювання відносин, що виникають у процесі інклюзивного навчання. Це стосується $i$ осіб з особливими освітніми потребами, $i$ закладів освіти та інших державних інституцій, які беруть участь в організації та контролі за дотриманням норм в процесі інклюзивного навчання.

\section{Вступ}

у статті 26 Загальної декларації прав людини, проголошеної ООН 10 грудня 1948 року, закріплено право на освіту, яке належить до другого покоління прав і свобод людини і громадянина. Освіта відіграє найважливішу роль для всебічного розвитку людини як особистості, їі талантів, розумових і фізичних здібностей, виховання високих моральних якостей, здобуття професійних 
навичок та їх удосконалення. Неможливо не виділити цінності ролі освіти в розбудові державних інститутів та суспільства, оскільки саме вона $є$ основою їх розвитку в інтелектуальній, культурній, духовній, соціальній та економічній сферах. Відповідно, якість і рівень освіти напряму впливають на прогрес держави і суспільства.

Підписання Угоди про асоціацію України з ЄС $\epsilon$ безпосереднім юридичним фактом для виникнення спільних відносин у галузі міжнародної політики, економіки, освіти, науки, культури тощо. Відповідно, перед нашою державою постала нагальна потреба запровадити нововведення, що спрямовані на застосування європейських стандартів освіти та наближення вітчизняної системи освіти до загальноєвропейського освітнього рівня. Усе це передбачає покращення якості знань, запровадження інноваційних технологій, удосконалення системи організації навчального процесу й оцінювання якості знань. Також реформування освіти в Україні спрямоване на вирішення питання забезпечення рівного вільного доступу до освіти усіх членів суспільства. Право на освіту закріплено в Основному законі України (стаття 53) та включає у себе право здобувати освіту впродовж усього життя, право на доступність освіти, право на безоплатну освіту у випадках і порядку, визначених Конституцією та законами України. Також право на освіту гарантується незалежно від віку, статі, раси, стану здоров'я, інвалідності, громадянства, національності, політичних, релігійних чи інших переконань, кольору шкіри, місця проживання, мови спілкування, походження, соціального і майнового стану, наявності судимості, а також інших обставин та ознак(стаття 3 Закону України «Про освіту» від 5 вересня 2017 року).

Прийняття Закону України «Про освіту» від 5 вересня 2017 року та Закону України «Про внесення змін до деяких законів України щодо доступу осіб з особливими освітніми потребами до освітніх послуг» 6 вересня 2018 року стало важливим кроком для наближення української системи 
освіти до європейських стандартів рівності та доступності освіти. Адже цими нормативно-правовими актами закріплено правове регулювання освітніх послуг для осіб з особливими освітніми потребами.

\section{1. Виникнення та розвиток інклюзивної освіти у світі та Україні}

Світові процеси глобалізації, гуманізації та демократизації безпосередньо впливають на модернізацію освітніх систем, що першочергово проявляється в поступовому переході традиційної моделі освіти до інклюзивної. Проте так було не завжди, і для усвідомлення важливості та необхідності впровадження інклюзивного навчання було пройдено декілька історичних етапів.

Видатними вченими в галузі педагогіки Колупаєвою А.А., Таранченко О.M. виділено такі періоди становлення інклюзивної освіти у світі:

- перший період (996-1715 рр.) - від агресії та зневаги до усвідомлення необхідності піклуватися про людей із відхиленнями в розвитку. У Німеччині відкирвається перший притулок для сліпих (1198 р);

- другий період (1715-1806 рр.) - від усвідомлення необхідності піклуватися про осіб із відхиленнями в розвитку до усвідомлення навчати частину з них. У Франції відкриваються спеціальні школи для глухонімих і сліпих (1770-1784 pp.);

- третій період (1806-1927 рр.) - від усвідомлення можливостей до усвідомлення доцільності навчати три категорії дітей: із порушеннями слуху, зору та розумово відсталих. Здійснюється прийняття в західноєвропейських державах законів про загальну початкову освіту і на цій основі - законів про навчання глухих, сліпих і розумово відсталих дітей.

- четвертий період (1927-1991рр.) - від усвідомлення необхідності навчання певної частини дітей із порушеннями до розуміння необхідності навчати всіх дітей 
із відхиленнями в розвитку. У країнах Західної Європи ухвалюються антидискримінаційні законодавчі акти, що затверджуються 3 урахуванням основних положень Декларацій ООН.

- п’ятий період (1991 р. - й донині) - від сегрегативного навчання дітей з особливими освітніми потребами до інклюзивної освіти. У Західній Європі з кінця 70-х років значно скорочується кількість спеціальних шкіл, збільшується кількість спеціальних класів у загальноосвітніх школах, учнів з особливими освітніми потребами починають навчати в загальноосвітніх школах в інклюзивному середовищі [1, с. 10-13].

Розвитку інклюзивного навчання сприяло прийняття низки міжнародних нормативно-правових актів, якими закріплено ключові цінності під час використання права на освіту, а саме рівності, доступності, недискримінації. Цей шлях транформації системи освіти можна періодизувати за прийнятими міжнародними документами.

1. Загальна декларація прав людини (1948) - закріпила право людини на освіту, яка має бути безоплатною (початкова та загальна) i обов'язковою (початкова), загальнодоступною (технічна і професійна), рівно доступною (вища), має сприяти взаєморозумінню, терпимості і дружбі між усіма народами, расовими або релігійними групами[2].

2. Конвенція про боротьбу з дискримінацією в галузі освіти (1960) визначила поняття «дискримінація» як відмінність, виняток, обмеження або перевагу за ознакою раси, кольору шкіри, статі, мови, релігії, політичних або інших переконань, національного або соціального походження, економічного становища або місця народження, що має на меті (або наслідком якої є) знищення чи порушення рівності у сфері освіти [3].

3. Міжнародний пакт про економічні, соціальні i культурні права (1966) - передбачено право кожної людини на обов'язкову та безоплатну початкову освіту, 
а також поступовий перехід до безоплатної середньої і вищої освіти [4].

4. Конвенція про права дитини (1989) - закріплено, що освіта $€$ самоцінною і визнається найголовнішим правом кожної особи, а держави визнають право дитини на освіту 3 метою поступової реалізації цього права на основі надання рівних можливостей, визначено, що неповноцінна в розумовому або фізичному відношенні дитина має вести повноцінне і достойне життя в умовах, які забезпечують ії гідність, сприяють почуттю впевненості в собі та полегшують іï активну участь у житті, неповноцінна дитина має право на ефективний доступ до послуг у сфері освіти, професійної підготовки, медичного обслуговування, відновлення здоров'я, підготовки до трудової діяльності і доступу до засобів відпочинку, що призводить до найбільш повного залучення дитини в соціальне життя та досягнення розвитку її особистості, включаючи культурний і духовний розвиток дитини [5].

5. Всесвітня декларація про освіту для всіх (1990) визначено необхідність загального доступу до навчання, сприяння забезпеченню рівності, збільшення засобів i масштабів базової освіти, покращення умов для освіти та зміцнення партнерських зв'язків, забезпечення рівного доступу до освіти осіб 3 інвалідністю як невіддільної частини системи освіти [6].

6. Стандартні правила забезпечення рівних можливостей для осіб з інвалідністю (1993) - визначено принципи рівних можливостей у сфері початкової, середньої і вищої освіти для дітей, молоді і дорослих, які мають інвалідність, зазначено, що освіта осіб 3 інвалідністю $\epsilon$ обов'язковою і невіддільною частиною системи загальної освіти, а держава має забезпечити гнучкість освітніх програм, надавати високоякісні навчальні матеріали, покращити підготовку педагогічних працівників[7].

7. Саламанська декларація (1994) - вперше введено поняття інклюзивного навчання, інклюзивної школи та 
особливих освітніх потреб. Визначено, що школи повинні приймати всіх дітей, незважаючи на їхні фізичні, інтелектуальні, соціальні, емоційні, мовленнєві або інші особливості, освітні заклади мають шукати шляхи успішного навчання всіх дітей, включаючи дітей, у яких $\epsilon$ серйозні порушення розвитку та інвалідність, закріплено основні принципи інклюзивної школи, які полягають у тому, що всі діти повинні навчатися разом у будь-яких випадках, коли це $\epsilon$ можливим, незважаючи ні на які труднощі або відмінності, що існують між ними, а зарахування дітей у спеціальні школи чи класи має бути винятком, рекомендованим тільки в тих рідкісних випадках, коли абсолютно очевидним $є$ те, що навчання у звичайних класах не здатне задовільнити освітні чи соціальні потреби будь-якої дитини або якщо це необхідно для благополуччя цієї дитини чи інших дітей. Закріплено, що розвиток інклюзивних шкіл як найефективніший засіб забезпечення освітою всіх необхідно визнати основним напрямом державної політики i виділити його як пріоритет у програмах розвитку країни [8].

8. Копенгагенська декларація про соціальний розвиток (1995) - визначено, що держави мають сприяти доступу дітей до закладів освіти і забезпечити якість освіти 3 метою усунення нерівності, пов'язаної із соціальними умовами, і відмінностей за ознакою раси, національного походження, статі, віку або інвалідності [9].

9. Дакарські рамки дій (2000) - наголошено на необхідності створення безпечних, здорових, інклюзивних умов у сфері освіти, що сприяють успішному навчанню [10].

10. Конвенція ООН про права осіб 3 інвалідністю (2006) - визнано право осіб з інвалідністю на освіту, забезпечення інклюзивної освіти на всіх рівнях упродовж усього життя, неможливість виключення осіб через їхню інвалідність із системи загальної освіти, а дітей 3 інвалідністю - із системи безоплатної та обов'язкової початкової або середньої освіти, забезпечення розумного пристосування, що враховує індивідуальні потреби, 
отримання всередині системи загальної освіти необхідної підтримки для полегшення ефективного навчання [11].

11. Інчхонська декларація (2015) - наголошено на необхідності забезпечити інклюзивну та якісну освіту на рівноправній основі, надати кожній людині можливість здобувати освіту впродовж усього життя [12].

Система освіти для осіб 3 певними порушеннями розвитку в Україні розвивалась поетапно від окремих спроб індивідуального навчання, організації групового навчання і до створення окремих навчальних закладів. Науковцями виокремлено кілька періодів становлення системи освіти осіб з порушеннями розвитку в Україні:

I період (X - перша половина XIX ст.) - період формування системи церковної благодійності в закладах при цервах і монастирях.

II період (перша половина XIX - початок XX ст.) - період філантропічного благочинництва та відкриття перших приватних закладів для різних категорій дітей 3 порушеннями розвитку.

III період (до 30-х років XX ст.) - період законодавчонормативного та організаційного оформлення системи освіти осіб 3 порушеннями розвитку; оформлення діагностичних підходів та відповідної практики відбору дітей до закладів освіти.

IV період (30-50-ті роки XX ст.) - період загальносоюзної уніфікації освіти; оформлення спеціальної системи освіти осіб 3 порушеннями розвитку; науково-теоретичне обгрунтування диференційованого навчання різних категорій дітей із порушеннями та практичне впровадження їх у відповідних закладах освіти.

V період (50-90-ті роки XX ст.) - період удосконалення та розширення мережі закладів системи спеціальної освіти; наукове вдосконалення підходів, 3 урахуванням нових технічних досягнень.

VI період (90-ті роки XX ст.- сучасність) - період розбудови національної системи освіти; перегляд концептуальних підходів щодо освіти осіб із порушеннями 
розвитку у відповідності із законодавчими актами міжнародного рівня та враховуючи соціальні зміни в суспільстві; впровадження інклюзивної практики [1, с. 14].

\section{2. Нормативно-правове забезпечення}

\section{права на інклюзивну освіту}

Після ратифікації Верховною Радою України Конвенції ООН про права осіб з інвалідністю 16.12.2009 року наша держава взяла на себе зобов'язання забезпечити реалізацію прав осіб з інвалідністю, зокрема їхнє право на освіту. Як наслідок до закону України «Про загальну середню освіту» були внесені зміни, згідно з якими діти 3 особливими освітніми потребами отримали можливість здобувати загальну середню освіту дистанційно або в спеціальних чи інклюзивних класах. Крім того, для виконання положень конвенції було прийнято низку нормативно-правових актів, зокрема:

1. Розпорядження КМУ «Про затвердження плану заходів щодо запровадження інклюзивного та інтегрованого навчання у загальноосвітніх закладах на період до 2012 року»;

2. Постанова КМУ «Про затвердження Порядку організації інклюзивного навчання»;

3. Наказ МОН України «Про затвердження Концепції розвитку інклюзивного навчання»;

4. Наказ МОН України «Про організацію інклюзивного навчання у загальноосвітніх навчальних закладах».

Варто зазначити, що прийняття зазначених актів не сприяло системному впровадженню інклюзивного навчання, а його реальний розвиток розпочався із ухвалення закону України від 23.05.2017 року «Про внесення змін до Закону України «Про освіту» щодо особливостей доступу осіб 3 особливими освітніми потребами до освітніх послуг». Адже саме ці зміни торкнулися реалізації права осіб з особливими освітніми потребами, передбачили зобов'язання закладів загальної середньої освіти за зверненням представників осіб 3 
особливими освітніми потребами створювати інклюзивні класи, надання гарантій на отримання психологопедагогічних, корекційно-розвивальних послуг, навчання за допомогою найбільш доступних для таких осіб мови, методів спілкування.

Міністерством освіти і науки України було затверджено «Примірне положення про команду психолого-педагогічного супроводу дитини 3 особливими освітніми потребами в закладі загальної середньої та дошкільної освіти». Цим положенням врегульовано внутрішній процес організації інклюзивного навчання, передбачено команду психолого-педагогічного супроводу, яка включає в себе директора чи заступника директора з навчально-виховної роботи, вчителя початкових класів або класного керівника, вчителів, асистентів вчителя, практичного психолога, соціального педагога, вчителя-дефектолога, вчителяреабілітолога, працівника інклюзивно-ресурсного центру та батьків чи законних представників дитини. Крім того, для організації інклюзивного навчання осіб з особливими освітніми потребами в закладах середньої освіти введено посаду асистента вчителя на клас [13]. Також встановлено доплату в розмірі двадцяти відсотків від заробітної плати педагогічним працівникам та помічникам вихователів закладів освіти за роботу в інклюзивних класах [14].

У Концепції розвитку інклюзивної освіти визначено основні принципи інклюзивної освіти:

- науковість (розроблення теоретико-методологічних основ інклюзивного навчання, програмно-методичного інструментарію, аналіз і моніторинг результатів упровадження інклюзивного навчання, оцінка ефективності технологій, що використовуються для досягнення позитивного результату, проведення незалежної експертизи);

- системність (забезпечення рівного доступу до якісної освіти дітей 3 особливими освітніми потребами, наступності між рівнями освіти: рання допомога дошкільна освіта - загальна середня освіта); 
- варіативність, корекційна спрямованість (організація особистісно-орієнтованого навчального процесу у комплексі 3 корекційно-розвитковою роботою для задоволення соціально-освітніх потреб, створення умов для соціально-трудової реабілітації, інтеграції в суспільство дітей із порушеннями психофізичного розвитку, у тому числі дітей-інвалідів);

- індивідуалізація (здійснення особистісно-орієнтованого індивідуального, диференційованого підходу);

- соціальна відповідальність сім'ї (виховання, навчання і розвиток дитини; створення належних умов для розвитку їі природних здібностей, участь у навчальнореабілітаційному процесі);

- міжвідомча інтеграція та соціальне партнерство (координація дій різних відомств, соціальних інституцій, служб із метою оптимізації процесу освітньої інтеграції дітей з особливими освітніми потребами) [15].

Загалом стану законодавства у сфері інклюзивної освіти в Україні характерні такі риси:

1. Гарантування рівного доступу до якісної освіти дітей з особливими освітніми потребами, права вибору різних типів закладів освіти і форм навчання.

2. Розширення практики інклюзивної освіти в закладах дошкільної, загальної середньої, позашкільної, професійної (професійно-технічної) і вищої освіти.

3. Реформування системи шкіл-інтернатів i забезпечення навчання дітей за місцем їх проживання.

4. Зростання уваги до своєчасної комплексної психолого-педагогічної оцінки розвитку дитини і надання їй психолого-педагогічних, корекційно-розвиткових послуг.

5. Індивідуаліція освітнього процесу шляхом розробки індивідуальної програми розвитку і здійснення особистісно орієнтованого (індивідуального, диференційованого) навчання.

6. Введення у штати закладів освіти посади вчителівдефектологів, ставки асистента вчителя. 
7. Міжвідомча інтеграція та соціальне партнерство (залучення батьків і представників різних відомств, соціальних інституцій, служб з метою оптимізації процесу освітньої інтеграції дітей 3 особливими освітніми потребами [16, с. 27].

\section{3. Правове регулювання інклюзивного навчання у сфері освітніх послуг}

Ратифікувавши основні міжнародні правові документи щодо права дітей з особливими освітніми потребами на рівний доступ до якісної освіти, Україна почала впроваджувати інклюзивне навчання в національну систему освіти, закріпивши це в низці нормативноправових актів.

Одним із найважливіших кроків для реалізації принципів інклюзивної освіти стало прийняття закону України «Про освіту». Саме цим законом визначено поняття інклюзивного навчання як системи освітніх послуг, гарантованих державою, що базується на принципах недискримінації, врахування багатоманітності людини, ефективного залучення та включення до освітнього процесу всіх його учасників. Серед засад державної політики в освітній сфері виділено також ті, що безпосередньо зв'язані із принципами інклюзивної освіти загалом. Це забезпечення рівного доступу до освіти без дискримінації за будь-якими ознаками, в тому числі за ознакою інвалідності, розвиток інклюзивного освітнього середовища, в тому числі в закладах освіти, найбільш доступних i наближених до місця проживання осіб 3 особливими освітніми потребами, та забезпечення універсального дизайну та розумного пристосування.

Із метою наближення принципів інклюзивного навчання в Україні до світових стандартів у законодавстві було введено поняття особи 3 особливими освітніми потребами, якою $є$ особа, що потребує додаткової постійної чи тимчасової підтримки в освітньому процесі з метою 
забезпечення їі права на освіту[17]. А законом України «Про вищу освіту» особу 3 особливими освітніми потребами визначено як особу з інвалідністю, яка потребує додаткової підтримки для забезпечення здобуття вищої освіти [18]. Законодавством України роз'яснено поняття особи з інвалідністю як особи зі стійким розладом функцій організму, що під час взаємодії із зовнішнім середовищем може призводити до обмеження її життєдіяльності, внаслідок чого держава зобов'язана створити умови для реалізації нею прав нарівні 3 іншими громадянами та забезпечити іiї соціальний захист [19]. Проте визначення закону України «Про вищу освіту» особи з особливими освітніми потребами суперечить п. 1 ст. 19 закону України «Про освіту», в якому зазначено, що органи державної влади та органи місцевого самоврядування створюють умови для забезпечення прав i можливостей осіб 3 особливими освітніми потребами для здобуття ними освіти на всіх рівнях освіти 3 урахуванням їхніх індивідуальних потреб, можливостей, здібностей та інтересів. Суперечність полягає в тому, що у особа 3 інвалідністю належить до однієї з багатьох категорій у переліку категорій осіб з особливими освітніми потребами.

Так категорії осіб з особливими освітніми потребами визначаються актами Кабінету Міністрів України 3 урахуванням міжнародних норм і стандартів. Кабмін у Постанові № 952 від 14.11.2018 року «Про деякі категорії осіб з особливими освітніми потребами» визначив, що до категорії осіб $з$ особливими освітніми потребами, які потребують розумного пристосування для проходження зовнішнього незалежного оцінювання, належать особи, які здобувають (здобували) повну загальну середню освіту мовою, що не належить до слов'янської групи мов, особи, які здобувають (здобували) повну загальну середню освіту мовою корінних народів [20].

До прийняття Постанови КМУ № 952 від 14.11.2018 року Міністерством освіти і науки України було розроблено та запропоновано для громадського обговорення проект 
Постанови «Про затвердження Переліку деяких категорій осіб з особливими освітніми потребами». У цьому акті визначено перелік осіб з особливими освітніми потребами, до якого належать:

- особи з порушеннями зору, слуху, опорно-рухового апарата; хворобами нервової системи; затримкою психічного розвитку, інтелектуальними порушеннями, складними порушеннями мовлення (в тому числі 3 дислексією);

- іншими складними порушеннями розвитку (в тому числі з розладами спектру аутизму);

- особи, яким встановлено електрокардіо-стимулятор або інший електронний імплантат чи пристрій;

- особи, які мають захворювання, що можуть бути перешкодою для проходження зовнішнього незалежного оцінювання, визначені МОН спільно з МО3;

- особи, які мають захворювання, що потребують постійного медичного нагляду, або періодичного здійснення індивідуальних медичних процедур із забезпечення життєдіяльності людини та/або контролю за її станом;

- особи, які потребують відновлення стану здоров'я в закладах загальної середньої освіти санаторного типу;

- особи, які опинились у складних життєвих обставинах, влаштовані до дитячих будинків сімейного типу, соціально-реабілітаційних центрів, перебувають у школах соціальної реабілітації;

- особи, які проживають на тимчасово окупованій території або в населених пунктах, на території яких органи державної влади тимчасово не здійснюють свої повноваження, або в населених пунктах, що розташовані на лінії зіткнення;

- особи, які мають статус внутрішньо переміщених;

- діти-біженці та діти, які потребують додаткового та тимчасового захисту;

- особи, які здобувають спеціалізовану освіту та/або можуть прискорено опанувати зміст навчальних предметів одного чи декількох класів, освітніх рівнів; 
- особи, які здобувають(ли) повну загальну середню освіту мовою, що не належить до слов'янської групи мов, або базову чи профільну середню освіту - мовою корінних народів (особи 3 особливими мовними освітніми потребами).

Проаналізувавши вище вказані нормативно-правові акти, оцінюючи суттєву відмінність у них, можемо зробити висновок, що i досі в Україні не визначено на законодавчому рівні перелік категорій осіб з особливими освітніми потребами. Дана прогалина в законодавстві обмежує можливість певних категорій населення на користування своїм конституційним правом на освіту. Хоча законом «Про освіту» передбачено, що заклади освіти в обов'язковому порядку утворюють інклюзивні та/або спеціальні групи і класи для навчання осіб з особливими освітніми потребами у разі їхнього звернення. Проте на практиці виникає проблема, що освітні заклади не охоче реагують на такі звернення, оскільки законом не передбачений конкретний перелік осіб 3 особливими освітніми потребами, а це дозволяє їм відсилати цих осіб чи їхніх законних представників у різні установи для доказування своєї належності до такої категорії.

У пункті 4 Наказу Міністерства освіти і науки України від 16.04.2018 № 367, зареєстрованого в Міністерстві юстиції України 05 травня 2018 р. за № 564/32016 «Про затвердження Порядку зарахування, відрахування та переведення учнів до державних та комунальних закладів освіти для здобуття повної загальної середньої освіти» вказано, що зарахування до закладу освіти здійснюється відповідно до наказу його керівника, що видається на підставі заяви про зарахування до закладу освіти (далі заява про зарахування) одного 3 батьків дитини (чи повнолітньої особи, яка має намір здобувати освіту), поданої особисто (із пред'явленням документа, що посвідчує особу заявника). У цьому ж порядку чітко вказано, які саме документи мають додати до заяви батьки (законні представники дитини). Серед переліку документів 
$\epsilon$ Висновок про комплексну (чи повторну) психологопедагогічну оцінку розвитку дитини чи витягу з протоколу засідання психолого-медико-педагогічної консультації, а висновок лікарсько-консультативної комісії закладу охорони здоров'я не може бути підставою для організації інклюзивного навчання для дитини 3 особливими освітніми потребами.

Висновок про комплексну (чи повторну) психологопедагогічну оцінку розвитку дитини, яка має особливі освітні потреби, роблять спеціалісти 3 найближчого до місця проживання дитини інклюзивно-ресурсного центру. Інклюзивно-ресурсний центр є установою, що утворюється 3 метою забезпечення права дітей з особливими освітніми потребами віком від 2 до 18 років на здобуття дошкільної та загальної середньої освіти, в тому числі в закладах професійної (професійно-технічної) освіти та інших закладах освіти, які забезпечують здобуття загальної середньої освіти, шляхом проведення комплексної психолого-педагогічної оцінки розвитку дитини (далі комплексна оцінка), надання психолого-педагогічних, корекційно-розвиткових послуг та забезпечення їх системного кваліфікованого супроводу [21].

Команда супроводу особи 3 особливими освітніми потребами впродовж двох тижнів 3 моменту початку освітнього процесу складає індивідуальну програму розвитку на основі висновку інклюзивно-ресурсного центру, індивідуальної програми реабілітації дитини 3 інвалідністю (за наявності), результатів психо-педагогічного вивчення дитини. Індивідуальна програма розвитку подається для погодження батькам чи законним представникам особи з особливими освітніми потребами, а після цього затверджується керівником освітнього закладу. Після затвердження індивідуальна програма розвитку переглядається двічі на рік у закладах загальної середньої освіти, а в закладах дошкільної освіти - тричі на рік.

Способи адаптації освітнього середовища та навчальні матеріали визначаються командою супроводу відповідно 
до потенційних можливосте та 3 урахуванням індивідуальних особливостей дитини [22].

Загалом право на освіту не може бути обмеженим і тому будь-яка особа може навчатися в закладах освіти усіх рівнів і ступенів. Особи з особливими освітніми потребами мають таке беззаперечне право і можуть ним скористатись, подавши відповідне звернення до обраного нею навчального закладу. Проте в системі освіти передбачені і спеціальні заклади освіти, в яких виховуються або навчаються виключно діти 3 особливими освітніми потребами. До них належать:

Заклади дошкільної освіти для дітей 3 особливими освітніми потребами:

1) ясла-садок компенсуючого типу (для дітей 3 особливими освітніми потребами віком від двох до семи (восьми) років, поділяються на спеціальні та санаторні);

2) будинок дитини (для медико-соціального захисту дітей-сиріт і дітей, позбавлених батьківського піклування, а також для дітей з фізичними та (або) інтелектуальними порушеннями від народження до трьох (для здорових дітей) та до чотирьох (для хворих дітей) років);

3) ясла-садок комбінованого типу(для дітей віком від одного до шести (семи, восьми) років, у складі якого можуть бути групи загального розвитку, компенсуючого типу, інклюзивні, сімейні, прогулянкові, в яких забезпечується дошкільна освіта 3 урахуванням стану здоров'я дітей, їхнього розумового, психологічного, фізичного розвитку);

4) центр розвитку дитини (в якому забезпечуються фізичний, розумовий і психологічний розвиток, корекція психологічного і фізичного розвитку, оздоровлення дітей, які відвідують інші навчальні заклади чи виховуються вдома) [23].

Заклади загальної середньої освіти для осіб 3 особливими освітніми потребами:

1. Спеціальна школа (для дітей з порушеннями слуху; для дітей із порушеннями зору; для дітей із порушеннями 
опорно-рухового апарату; для дітей із порушеннями інтелектуального розвитку; для дітей із тяжкими порушеннями мовлення).

2. Навчально-реабілітаційний центр (для дітей, які мають порушення слуху в поєднанні 3 порушеннями інтелектуального розвитку та/або порушеннями опорнорухового апарату; для дітей, які мають порушення зору в поєднанні із тяжкими системними мовленнєвими порушеннями чи порушеннями інтелектуального розвитку та/або порушеннями опорно-рухового апарату, та сліпоглухих дітей; для дітей, які мають порушення опорнорухового апарату в поєднанні 3 тяжкими системними мовленнєвими порушеннями чи порушеннями інтелектуального розвитку; для дітей із порушеннями інтелектуального розвитку в поєднанні 3 тяжкими порушеннями мовлення) [24].

\section{Висновки}

Особи 3 особливими освітніми потребами можуть реалізувати своє конституційне право на освіту за різними моделями навчання. Науковцями виділено такі моделі:

- медична - передбачає сегрегаційне навчання дітей $з$ обмеженими можливостями здоров'я у спеціальних закладах інтернатного типу;

- нормалізаційна (інтеграційна) - забезпечує доступ дітей з обмеженими можливостями здоров'я до навчання в загальноосвітній школі з урахуванням їхньої адаптації до наявних у ній умов: інтегроване навчання в корекційних класах загальноосвітньої школи;

- соціальна (інклюзивна) - грунтується на зміні освітнього середовища таким чином, щоб воно забезпечувало рівну участь своїх громадян у здійсненні їх прав; створенні єдиного освітнього середовища для навчання дітей із різним рівнем психофізичного здоров'я, або інклюзивне навчання як включення дітей 3 особливими освітніми потребами у спільне навчання 3 дітьми нормативного розвитку у загальноосвітній школі. 
Остання модель навчання $є$ інноваційним підходом до навчання дітей з особливими освітніми потребами. Адже інклюзивна освіта передбачає модифікацію освітньої програми та освітнього середовища до потреб учнів, які відрізняються своїми навчальними можливостями. Інклюзія в освіті реалізується через такі кроки:

1) створення таких умов, за яких усі учні мають однаковий доступ до освіти, в тому числі діти 3 особливими освітніми потребами, які навчаються в загальноосвітніх школах;

2) надання можливості іншим учням отримати досвід, знання, які сприяють подоланню упереджень й дискримінації та сприяють формуванню позитивного ставлення до тих, хто «відрізняється».

Відзначаючи позитивні зміни, які відбулись у нашій державі у сфері надання освіти для осіб з особливими освітніми послугами за останнє десятиліття, не можна не підкреслити ті проблеми, які й досі залишаються:

- вітчизняна система освіти має високий рівень уніфікованості, що перешкоджає забезпеченню освітніх потреб усіх учнів, які мають особливості психофізичного розвитку, ускладнює впровадження різних навчальних програм та внесення необхідних змін та додатків до навчальних планів;

- діти з психофізичними порушеннями ізольовані в спеціальних школах-інтернатах, які сьогодні $є$ основними спеціальними освітніми закладами, а це спричиняє відокремлення сім'ї від виховного процесу та обмеженість розвитку у дітей інших життєвих компетенцій;

- недостатня соціально-практична спрямованість навчального процесу, наслідками якої $\epsilon$ : низький рівень сформованості соціально-побутової компетентності учнів, незадовільна орієнтація в системі соціальних норм і правил та відсутність навичок самостійної життєдіяльності;

- недостатня індивідуалізованість та особистісна зорієнтованість навчально-виховного процесу, наслідками якої $\epsilon$ труднощі емоційного та особистісного розвитку 
учнів, неадекватні уявлення про свої якості, здібності й можливості;

- низька ефективність корекційно-розвивальних занять, що зумовлює низький рівень комунікативної компетентності, замкнутості, ізольованості;

- відсутність ліцензійного психолого-педагогічного інструментарію для діагностики порушень, що ускладнює правильне комплектування спеціальних закладів й організацію відповідного навчання;

- недостатнє науково-методичне та навчальне забезпечення освітнього процесу дітей 3 важкими патологіями, атиповими порушеннями, що потребують додаткових освітніх та корекційно- реабілітаційних послуг [1, с. 33].

Інклюзивне навчання покликане до створення якісних змін в особистому розвитку дітей з особливими освітніми потребами, організації нового освітнього середовища, яке б відповідало потребам і можливостям кожної дитини, незалежно від особливостей ії психофізичного розвитку, сприяння позитивному клімату у шкільному середовищі та поза його межами.

\section{Список використаних джерел:}

1. «Інклюзивна освіта: від основ до практики» : монографія / А.А. Колупаєва, О.М. Таранченко. Київ : ТОВ «АТОПОЛ», 2016. 152 с. (Серія «Інклюзивна освіта»).

2. Загальна декларація прав людини від 10.12.1948. URL: https://zakon.rada.gov.ua/laws/show/995_015.

3. Конвенція про боротьбу з дискримінацією в галузі освіти 14 грудня 1960 року URL: https://zakon.rada.gov.ua/laws/show/995_174.

4. Міжнародний пакт про економічні, соціальні і культурні права. URL: https://zakon.rada.gov.ua/laws/ show/995_042.

5. Конвенція про права дитини 20 листопада 1989 року. URL: https://zakon.rada.gov.ua/laws/show/995_021.

6. Всесвітня декларація про освіту для всіх. URL: https://zakon.rada.gov.ua/laws/show/995_001-94. 
7. Стандартні правила забезпечення рівних можливостей для осіб з інвалідністю від 20 грудня 1993 року. URL: https://zakon.rada.gov.ua/laws/show/995_306.

8. Саламанська декларація. URL: https://zakon.rada.gov.ua/ laws/show/995_001-94.

9. Копенгагенська декларація про соціальний розвиток. URL: https://zakon.rada.gov.ua/laws/show/995_505.

10. Дакарські рамки дій. URL: https://www.un.org/ru/ events/literacy/dakar.htm.

11. Конвенція ОOH про права осіб з інвалідністю. URL: https://zakon.rada.gov.ua/laws/show/995_g71.

12. Інчхонська декларація. URL: https://pon.org.ua/ international/4171-inchxonska-deklaraciya-koncepciyarozvitku-osviti.html.

13. Наказ Міністерства освіти і науки України «Про внесення змін до наказу Міністерства освіти і науки України від 06 грудня 2010 року № 1205» № 90 від 01.02.2018. URL: https://zakon.rada.gov.ua/laws/show/ z0226-18.

14. Постанова Кабінету Міністрів України від 14.02.2018 № 72 «Про внесення змін у додаток до постанови Кабінету Міністрів України від 25 серпня 2004 р. № 1096». URL: https://zakon.rada.gov.ua/laws/show/722018-\%D0\%BF.

15. Наказ Міністерства освіти і науки України «Про затвердження концепції розвитку інклюзивного навчання» від 01.10.2010 № 912. URL: https://mon.gov.ua/ua/npa/prozatverdzhennya-kontseptsii-rozvitku-inklyuzivnogo-navchannya.

16. Порошенко М.А. Інклюзивна освіта : навчальний посібник. Київ : ТОВ «Агентство Україна», 2019. 300 с.

17. Закон України «Про освіту» від 5 вересня 2017 року № 2145-VIII. Відомості Верховної Ради (ВВР). 2017. № 38-39. Ст. 380.

18. Закон України «Про вищу освіту» від 1 липня 2014 року № 1556-VII. Відомості Верховної Ради (ВВР). 2014. № 37-38. Ст. 2004. 
19. Закон України «Про основи соціальної захищеності осіб з інвалідністю в Україні» від 21 березня 1991 року № 875-XII. Відомості Верховної Ради УРСР (ВВР). 1991. № 21. Ст. 252.

20. Постанова Кабінету Міністрів України «Про деякі категорії осіб 3 особливими освітніми потребами» від 14 листопада 2018 р. № 952. URL: https://zakon.rada.gov.ua/ laws/show/952-2018-\%D0\%BF.

21. Постанова Кабінету Міністрів України «Про затвердження Положення про інклюзивно-ресурсний центр» від 12 липня 2017 p. № 545. URL: https://zakon.rada.gov.ua/laws/show/545-2017-\%D0\%BF.

22. Додаток до листа МОН від 05.08.2019 № 1/9 498 «Методичні рекомендації щодо організації навчання осіб з особливими освітніми потребами в закладах освіти в 2019/2020 н. p.». URL: https://mon.gov.ua/storage/app/ media/inkluzyvne-navchannya/2019/08/07/rekomendatsii organizatsiya-navchannyaoop.pdf.

23. Закон України «Про дошкільну освіту» від 11 липня 2001 року № 2628-III. Відомості Верховної Ради України (BBP). 2001. № 49. Ст. 259.

24. Постанова Кабінету Міністрів України «Про затвердження Положення про спеціальну школу та Положення про навчально-реабілітаційний центр» від 6 березня 2019 р. № 221. URL: https://zakon.rada.gov.ua/ laws/show/221-2019-\%D0\%BF. 